\title{
Quality characteristics of Moroccan sweet paprika (Capsicum annuum L.) at different sampling times
}

Naima ZAKI ${ }^{1}$, Abdelmalek HAKMAOUI ${ }^{1}$, Aaziz OUATMANE ${ }^{1}$, Juan Pablo FERNANDEZ-TRUJILLO ${ }^{2 *}$

\begin{abstract}
"La Niora" is a red pepper variety cultivated in Tadla Region (Morocco) which is used for manufacturing paprika after sun drying. The paprika quality (nutritional, chemical and microbiological) was evaluated immediately after milling, from September to December. Sampling time mainly affected paprika color and the total capsaicinoid and vitamin C contents. The commercial quality was acceptable and no aflatoxins were found, but the microbial load sometimes exceeded permitted levels.
\end{abstract}

Keywords: paprika; nutritional composition; physical-chemical properties.

\section{Introduction}

Pepper (Capsicum sp.) is grown in many countries of the world. In Morocco, red pepper (Capsicum annuum L.) for paprika is called "Niora" ( which is given to a certain group of pepper cultivars used for cooking and making paprika). The main production area is Tadla Region with more than $80 \%$ of the national production (HAKMAOUI; OUATMANE; FERNÁNDEZ-TRUJILLO, 2011). The plant material and the sun drying method used means that the paprika produced in Tadla resembles the paprika produced in Murcia (southeastern Spain) (ESCARABAJAL; FERNÁNDEZ-TRUJILLO, 2009; FERNÁNDEZ-TRUJILLO; ESCARABAJAL, 2006). Given the geographical location of Tadla, there is great interest in exporting paprika for distribution in Europe.

Paprika is a widely consumed condiment. The world supply is estimated at approximately 60,000 t per year, with an additional 1,400 $\mathrm{t}$ of paprika oleoresin (BUCKENHÜSKES, 2003). Paprika powder is used both domestically and for industrial purposes. In the food industry it is mainly used as a natural colorant to correct or reinforce the color of foodstuffs or to provide flavoring. It is also used in the pharmaceutical and cosmetic industries (FERNÁNDEZ-TRUJILLO, 2007; FERNÁNDEZ-TRUJILLO; ESCARABAJAL, 2006).

To obtain paprika, the pepper must be dehydrated by heating and then ground. Traditionally in Morocco and southeastern Spain, paprika is obtained by sun drying (SD) (CONDORI; SARAVIA, 2001; FERNÁNDEZ-TRUJILLO; ESCARABAJAL, 2006). It takes about 7-20 days (depending on the weather conditions) to reduce the moisture content to $10-15 \%$ (OBEROI et al., 2005). In Morocco, harvesting and sun drying is usually carried out over the four months from September to December (HAKMAOUI; OUATMANE; FERNÁNDEZ-TRUJILLO, 2011).

In paprika, food safety concerns usually refer to its microbial status and the possible presence of mycotoxins
(BUCKENHÜSKES, 2003; FERNÁNDEZ-TRUJILLO; ESCARABAJAL, 2006; VALLE-ALGARRA et al., 2011). Other quality attributes in paprika include its color intensity, taste, stability, pungency, ascorbic acid content and chemical compounds (ESCARABAJAL; FERNÁNDEZ-TRUJILLO, 2009; YALDIZ; OZGUVEN; SEKEROGLU, 2010).

The color of paprika mainly comes from the carotenoids formed in the fruit during ripening, with more than 20 different pigments identified (DELI; PFANDER; TÓTH, 2002; TOPUZ; FENG; KUSHAD, 2009). During processing and storage, color degradation kinetics can be modeled depending on temperature and water activity (TOPUZ, 2008). Capsanthin is the main carotenoid in paprika, followed by capsorubin and provitamin A carotenoids (GALLARDO-GUERRERO et al., 2010). In rats, capsanthin has positive effects on health by increasing the high density lipoprotein (HDL) cholesterol in plasma and can increase cholesterol efflux to HDL particles (AIZAWA; INAKUMA 2009). Harvesting the fruit in a very advanced stage of maturity can increase pericarp soluble pectin and calcium pectate, which has a detrimental effect on paprika quality due to the need of increasing processing time for pepper drying (GALLARDO-GUERRERO et al., 2010).

A high concentration of the antioxidant ascorbic acid in paprika plays a positive role in ensuring the stability of the final product (FERNÁNDEZ-TRUJILLO; ESCARABAJAL, 2006). However, paprika stored at $4{ }^{\circ} \mathrm{C}$ and $70 \%$ relative humidity without reconstitution of the antioxidant level shows reduced loss in carotenoids content due to autoxidation and similar quality attributes than before storage (PÉREZ-GÁLVEZ; HORNERO-MÉNDEZ; MÍNGUEZ-MOSQUERA, 2009). The stability of the main carotenoids of the red bell pepper during storage has been shown to depend on the drying conditions, with the rate of deterioration increasing as the drying temperature increases (DOYMAZ; PALA, 2002; VEGAGÁLVEZ et al., 2008). In addition to better color intensity at harvest, partial slow drying improves color retention in

\footnotetext{
Received 15/4/2013

Accepted 14/6/2013 (006067)

${ }^{1}$ EVAR, Faculté des Sciences et Techniques, Université Sultan Moulay Slimane, Beni Mellal, Beni Mellal, Marrocos

2 Department of Agricultural and Food Engineering, Universidad Politécnica de Cartagena - UPCT, Paseo Alfonso XIII, 48, ETSIA, 30203, Cartagena, Murcia, Spain, e-mail:juanp.fdez@upct.es

${ }^{*}$ Corresponding author
}

DOI: http://dx.doi.org/10.1590/S0101-20612013005000072 
spice because of additional recovery of fruit carotenogenesis and oxidative thermal-stress, particularly under illumination and after the first day of this process (PÉREZ-GALVEZ; HORNERO-MÉNDEZ; MÍNGUEZ-MOSQUERA, 2004), as red pigments are more stable than yellow pigments and betacarotene is converted to more stable red colored xanthophylls (MÁRKUS et al., 1999; MÍNGUEZ-MOSQUERA; HORNEROMÉNDEZ, 1994; MÍNGUEZ-MOSQUERA; JARÉN-GALÁN; GARRIDO-FERNÁNDEZ, 1994).

The fat content is another quality parameter of paprika pericarp as it is usually present in esterified form with carotenoids, providing a more homogenous and attractive spice (PÉREZ-GÁLVEZ; GARRIDO-FERNÁNDEZ; MÍNGUEZMOSQUERA, 1999).

The pungency of Capsicum species depends on the concentration of capsaicinoids, particularly capsaicin, in the pepper fruit. Usually, sweet paprika, the most commonly grown pepper in Morocco and Spain, has very low capsaicinoid content (FERNÁNDEZ-TRUJILLO; ESCARABAJAL, 2006). Capsaicinoids constitute a class of plant alkaloids, which are all fatty acid amides of vanil-lylamine (SCHWEIGGERT; CARLE; SCHIEBER, 2006). The major components are capsaicin, dihydrocapsaicin and nordihydrocapsaicin, accompanied by several minor capsicinoids which are present at very low levels and which are not thought to contribute greatly to overall pungency (PERUCKA; MATERSKA, 2001).

Paprika, besides imparting pungency and a red color to dishes, is a rich source of provitamin A and vitamins B, C and $\mathrm{E}$, and minerals like $\mathrm{K}, \mathrm{Ca}, \mathrm{P}, \mathrm{Fe}, \mathrm{Na}$ and $\mathrm{Cu}$ in trace amounts. Differences in the nutritional composition are determined by the cultivar, the growing conditions and fruit maturity, while further changes can occur during postharvest handling and storage (BOSLAND; VOTAVA, 2000).

The aim of this study was to evaluate main food composition attributes of Moroccan sweet paprika at four sampling times that can be affecting the quality of the product.

\section{Materials and methods}

The pepper fruits were harvested during 2010 in the Tadla Azilal region of Morocco. Paprika powder samples derived from 'Niora' cultivar (Capsicum annuum L.) were obtained by means of the process previously reported that essentially includes fruit sun drying and grinding (HAKMAOUI; OUATMANE; FERNÁNDEZ-TRUJILLO, 2011), but no extra oil was added. Powders were taken immediately after milling at four different sampling periods (during first week of September, October, November and December). The average particle size of the powders was $400 \mu \mathrm{m}$. The samples were stocked in hermetic containers in darkness and under refrigeration $\left(4^{\circ} \mathrm{C}\right)$ until analysis. Three replicates were used per harvest time obtained from three independent millings without adding oil. The samples for milling were taken randomly from different levels of the piles of sacks in which the collaborating companies store the sun dried peppers.

\subsection{Measurement of chemical composition and paprika color}

All analyses were made using analytical grade chemicals and reagents. The $\mathrm{pH}$ of the extract was obtained using a $\mathrm{pH}$ meter (Thermo Scientific Orion Star Series, USA) according to AOAC methods (HORWITZ, 2002). Pepper extracts were prepared by mixing $2 \mathrm{~g}$ powder sample with $80 \mathrm{~mL}$ distilled water in a shaker-incubator for $3 \mathrm{~h}$ at $200 \mathrm{rpm}$. Moisture of the samples was analyzed by weighing $5 \mathrm{~g}$ of the sample that was dried at $100^{\circ} \mathrm{C}$ for $6 \mathrm{~h}$ (AOAC method 925.05; HORWITZ, 2002). The total ash content of the samples was determined according to the official AOAC method 941.12 (HORWITZ, 2002), incinerating the samples in a muffle furnace at $525^{\circ} \mathrm{C}$ for $24 \mathrm{~h}$. Ashes were quantified gravimetrically.

The ASTA color value of paprika powders was determined according to the official AOAC method 971.26 (HORWITZ, 2002) with a slight modification. Samples $(0.1 \mathrm{~g})$ were extracted with $20 \mathrm{~mL}$ acetone for $3 \mathrm{~h}$ by using a water bath (axially shaken at $140 \mathrm{rpm}$ ) maintained at $25^{\circ} \mathrm{C}$. Then the extract was diluted $1 / 5$ with acetone. The absorbance of the diluted extract was measured against acetone at $460 \mathrm{~nm}$ by spectrophotometer. The extractable color of the samples was expressed in ASTA units: ASTA $=$ Absorbance ${ }^{\star} 16.4{ }^{*}$ devf/ weight (1), where devf is the deviation factor of the spectrophotometer, which was calculated by dividing the theoretical absorbance by the real absorbance of standard color solution $\left(0.001 \mathrm{M} \mathrm{K}_{2} \mathrm{Cr}_{2} \mathrm{O}_{7}\right.$ and $0.09 \mathrm{M}\left(\mathrm{NH}_{4}\right)_{2} \mathrm{Co}$ $\left(\mathrm{SO}_{4}\right)_{2} \cdot 6 \mathrm{H}_{2} \mathrm{O}$ in $\left.1.8 \mathrm{M} \mathrm{H}_{2} \mathrm{SO}_{4}\right)$ at $460 \mathrm{~nm}$.

Chemical color determination (Tint) was evaluated by dividing the absorption at $470 \mathrm{~nm}$ by the absorption at $455 \mathrm{~nm}$ of the acetone extracts (DE GUEVARA et al., 1996; HORNEROMÉNDEZ; MÍNGUEZ-MOSQUERA, 2001).

To measure skin color, a CR-300 chromameter (Minolta, Osaka, Japan) was used for (C illuminant, $0^{\circ}$ viewing) previously calibrating it with a white-plate standard. A glass Petri dish containing the samples was placed below the light source. The values of the coordinates $L^{*}, a^{*}$, and $b^{*}$ of each sample were determined in triplicate. Because chroma (C) and Hue angle $\left(h^{\circ}\right)$ have been shown to be more practical measures of color from an human sensorial point of view (McGUIRE, 1992), both parameters were calculated:

$\mathrm{C}=\left(\mathrm{a}^{* 2}+\mathrm{b}^{* 2}\right)^{1 / 2}$ and $\mathrm{h}^{\circ}=\arctan \left(\mathrm{b}^{*} / \mathrm{a}^{*}\right)$

\subsection{Determination of nutritional attributes and chemical composition of paprika powders}

The sugar content was determined using the Bertrand method by collecting the precipitate of the copper (II) oxide Cu2O formed by reduction of the copper-alkaline solution, in presence of reducing sugars, and to measure it out by manganimetry (BROWNE; ZERBAN, 1955). The crude fiber content of the raw Capsicum flour samples was determined by adding different concentrations of ethanol to cause selective precipitation of dietary fibers and then determined gravimetrically by weighing the mass of an insoluble fiber fraction isolated from a sample (AOAC 982.29 method, PROSKY et al., 1992). The oil content was analyzed gravimetrically after Soxhlet extraction using $10 \mathrm{~g}$ 
of paprika powder and $100 \mathrm{~mL}$ hexane as solvent following the AOAC No. 960.39 (HORWITZ, 2002). The solvent was removed by a rotary evaporator at $40{ }^{\circ} \mathrm{C}$. The fatty acid composition of oil was determined in a mixture of subsamples of the three replicates following the European Standard ISO 12966:2011 (EUROPEAN..., 2011). Briefly $0.1 \mathrm{~g}$ of the oil was dissolved in $2 \mathrm{~mL}$ isooctane and $0.1 \mathrm{~mL} \mathrm{KOH}(2 \mathrm{~N})$. The closed tube was stirred vigorously for $1 \mathrm{~min}$ at room temperature. The reaction of methylation was carried out after heating the mixture for 15 min at $80^{\circ} \mathrm{C}$ in a water bath and then allowing the tube to cool at $25^{\circ} \mathrm{C}$. Then, $0.2 \mathrm{~mL}$ of $15 \% \mathrm{MeOH} / \mathrm{H}_{2} \mathrm{SO}_{4}$ was added and the mixture was heated again for $15 \mathrm{~min}$ with a subsequent cooling at $25^{\circ} \mathrm{C}$ before adding $1 \mathrm{~mL}$ isooctane together with $2 \mathrm{~mL}$ of a $6.83 \mathrm{M}$ solution of sodium chloride to help in the transfer of the methyl esters to the organic phase. Then the tube was centrifuged at $4500 \mathrm{rpm}$ for $10 \mathrm{~min}$. The fraction of isooctane was removed in a test tube, which $1 \mathrm{~g}$ sodium bisulfate monohydrate was added. After centrifugation at $4500 \mathrm{rpm}$ for $10 \mathrm{~min}$, the top isooctane phase was transferred to a vial and injected into a Varian 5890 gas chromatograph with a CP-Sil 88 capillary column ( $100 \mathrm{~m}$ long, $0.25 \mathrm{~mm}$ ID, film thickness $0.2 \mathrm{~mm}$; Varian Deutschland, Darmstadt, Germany).

Total nitrogen was determined by the Kjeldahl method with two steps (mineralization and distillation) (POMERANZ; CLIFTON, 1987). Total nitrogen was converted into protein content by multiplying the $\mathrm{N}$ value by the factor 6.25 .

The energy content of the red pepper paprika was determined by multiplying the values obtained for protein, total carbohydrates and total fat by $4.00,3.75$, and 9.00 , respectively, and adding the results, as described in Durucasu and Tokusoglu (2007). The final results were multiplied by 4.1868 to express the energy content in $\mathrm{kJ}$. The vitamin $\mathrm{C}$ was determined using the method of Benderitter et al. (1998).

The capsaicinoid content was determined mixing paprika powder $(1 \mathrm{~g})$ with $10 \mathrm{~mL}$ of acetonitrile and kept for $4 \mathrm{~h}$ at $80^{\circ} \mathrm{C}$ with shaking in capped Erlenmeyer flask. The supernatant was filtered into a $2 \mathrm{~mL}$ glass vial by using a $0.45 \mu \mathrm{m}$ membrane filter (Millipore), and then used for HPLC injection (COLLINS; WASMUND; BOSLAND, 1995).

Capsaicinoid content was converted to the Scoville Heat Value (SHV) by multiplying the individual capsicinoid composition (in $\mathrm{mg} \mathrm{kg}^{-1}$ dry weight of the paprika) by the coefficient of the heat value for each individual compound, 9.3 for nordihydrocapsaicin (NDHCAPS) and 16.1 for both capsaicin (CAPS) and dihydrocapsaicin (DHCAPS) (TODD JUNIOR; BENSINGER; BIFTU, 1977).

Total SHV $=[$ CAPS + DHCAPS $] \times 16.1+[$ NDHCAPS $\times 9.3$

The mineral content was determined according to Osborne and Voogt (1978). Zinc, magnesium, iron, cadmium, lead and copper were analyzed by atomic absorption spectrophotometry using an UNICAM 929 AA Spectrometer ("ATIUNICAM"). Phosphorus was determined by the vanadomolybdophosphoricyellow method (JACKSON, 1985).

\subsection{Microbiological and aflatoxin analysis}

All samples were analyzed following AOAC methods for measuring total aerobic mesophilic bacteria, Enterobacteriaceae, total coliforms, fecal coliforms, Streptococcus, Staphylococcus aureus, Clostridium, yeast and mold (HORWITZ, 2002). Five grams of the pepper powder were mixed with $45 \mathrm{~mL}$ sterile peptone water solution in a Stomacher 400 Circulator (Seward, London, UK). Serial dilutions (1:10) of each homogenized sample were made in the same diluents and surface spread. Subsequent dilutions were prepared and plated on plate count agar for the total aerobic bacteria and on desoxycholate agar for coliforms. Microbial counting was performed 24-48 h after incubation at $30^{\circ} \mathrm{C}, 37^{\circ} \mathrm{C}$ and $46^{\circ} \mathrm{C}$ for total aerobic bacteria, total coliforms, and fecal coliforms, respectively. Enterobacteria were counted on VRBG medium and incubated at $37^{\circ} \mathrm{C}$ for 24-48 h. Clostridium genus was investigated on SPS medium at $46{ }^{\circ} \mathrm{C}$ for 24-48 h, Staphylococcus aureus were counted on BP medium and incubated at $37^{\circ} \mathrm{C}$ for $48 \mathrm{~h}$. Streptococcus were counted on Slanetz medium and incubated at $37^{\circ} \mathrm{C}$ for $24-48 \mathrm{~h}$. Detection of Salmonella was performed after enrichment and isolation on bismuth sulfite medium by incubating the plates at $37^{\circ} \mathrm{C}$ for at least $48 \mathrm{~h}$. Molds and yeasts were incubated on malt extract agar added with chloramphenicol at $25{ }^{\circ} \mathrm{C}$ for 4-7 d. The results of the analysis were always expressed as colony forming units per gram $(\mathrm{CFU} / \mathrm{g})$. The total aflatoxin content was determined according to Gilbert and Anklam (2002).

\subsection{Statistical analysis}

Analysis of variance of the data for each attribute was computed using the SPSS logiciel software version 10.0. When the effect of harvest time was significant, the Duncan test at $5 \%$ level of probability was used to test the differences among mean values.

\section{Results and discussion}

\subsection{Physical characteristics of paprika powders}

The $\mathrm{pH}$ of the paprika ranged from 5.1 to 6.3 and the moisture content between 8.6 and $10.8 \%$ with no significant difference between the times (Table 1). Paprika with a moisture content of less than $11 \%$ is deemed acceptable for marketing to ensure storage without mold growth (DOUGLAS; HEYES; SMALLFIELD, 2005). Moreover, the moisture content of paprika is very important because it is strongly correlated with the stability of ascorbic acid and pigment (KIM et al., 1982). Lee, Chung and Yam (1992) reported that dried pepper moisture content from 10 to $14 \%$ could retard color loss, while a content of less than $4 \%$ causes excessive color loss.

The total ash content of the paprika powders analyzed here ranged between 6.06 and 7.2\% (Table 1), which are below the maximum permissible limit value (10\%) according to ISO 7540 standard (BUCKENHÜSKES, 2003).

The AOAC (ASSOCIATION..., 2002) method is the most widely used to measure the commercial quality of paprika because quantifies the total carotenoid content indirectly. ASTA 
has been used as quality parameter in selection, breeding, and cultivar characterization (KIM; PARK; HWANG, 2002) and during the storage of the paprika under diverse conditions (PÉREZ-GALVEZ et al., 2004).

As regards extractable paprika color, the ASTA values of paprika ranged from $112 \pm 12$ (September) to $144 \pm$ 16 (November) (Table 1), both of which are considered acceptable (AMERICAN..., 1999). High quality and expensive paprika powders usually show ASTA values above 100. The extractable red/yellow pigments ratio ranged between 0.989 and 0.993 (Table 1), both in the range reported for paprika by Carvajal et al. (1997) and Topuz, Feng and Kushad (2009).
The CIELAB color parameters for paprika showed a decrease in lightness from September $(27.79 \%)$ to December (23.98\%) (Table 1$)$. The redness values $\left(\mathrm{a}^{\star}\right)$ did not change with sampling time but the yellowness $\left(\mathrm{b}^{*}\right)$ value and the color saturation index $C^{\star}$ decreased from September to December, indicating that the vividness of the powder color can be affected by, and perhaps due to, some continuous oxidation process. The hue angle index was around $46-49^{\circ}$ with no significant effect of harvest time. Any changes in the color parameters could have been the consequence of the agricultural conditions and/or meteorological factors, especially temperature, sunshine and rainfall (MÁRKUS et al. 1999), which are known to influence pigment levels in pepper fruits.

Table 1. Physical characteristics of paprika powders at different harvest times plus sun-drying and milling $(\mathrm{mean} \pm \mathrm{SD}, \mathrm{n}=3)$.

\begin{tabular}{|c|c|c|c|c|}
\hline \multirow{2}{*}{$\begin{array}{l}\text { Quality } \\
\text { parameter }\end{array}$} & \multicolumn{4}{|c|}{ Sampling time $(\text { month })^{z}$} \\
\hline & September & October & November & December \\
\hline $\mathrm{pH}$ & $5.1 \pm 0.3^{\mathrm{b}}$ & $5.4 \pm 0.6^{\mathrm{b}}$ & $6.25 \pm 0.3^{\mathrm{a}}$ & $5.42 \pm 0.5^{\mathrm{b}}$ \\
\hline Moisture (\%) & $10.80 \pm 1.6$ & $8.78 \pm 1.4$ & $10.03 \pm 1.1$ & $8.58 \pm 1.5$ \\
\hline Ash (\%) & $6.52 \pm 0.3$ & $7.16 \pm 0.7$ & $6.43 \pm 0.2$ & $6.06 \pm 0.3$ \\
\hline ASTA color units & $112 \pm 12^{c}$ & $117 \pm 5^{c}$ & $144 \pm 16^{\mathrm{a}}$ & $127 \pm 6^{\mathrm{b}}$ \\
\hline $\operatorname{Tint}^{y}$ & 0.989 & 0.990 & 0.990 & 0.993 \\
\hline \multicolumn{5}{|c|}{ Powder CIELAB color parameters } \\
\hline Lightness $\left(\mathrm{L}^{*}\right)$ & $27.79 \pm 2^{\mathrm{a}}$ & $27.04 \pm 1.5^{\mathrm{a}}$ & $24.56 \pm 0.5^{\mathrm{b}}$ & $23.98 \pm 0.7^{\mathrm{b}}$ \\
\hline $\mathrm{a}^{*}$ parameter & $29.5 \pm 1.2$ & $28.76 \pm 1.6$ & $29.14 \pm 1.4$ & $27.16 \pm 1.3$ \\
\hline $\mathrm{b}^{\star}$ parameter & $34 \pm 2.3^{\mathrm{a}}$ & $32.73 \pm 1.4^{\mathrm{a}}$ & $29.77 \pm 0.6^{\mathrm{b}}$ & $29.52 \pm 2.3^{b}$ \\
\hline Chroma index $\left(C^{\star}\right)$ & $45.01 \pm 1.2$ & $43.57 \pm 2.1$ & $41.66 \pm 2.3$ & $40.11 \pm 2.3$ \\
\hline Hue angle index $\left(\mathrm{h}^{0}\right)$ & $49.05 \pm 0.5$ & $48.69 \pm 2.4$ & $45.61 \pm 2.6$ & $47.38 \pm 2.3$ \\
\hline
\end{tabular}

${ }^{2}$ Samples were obtained in triplicate in the first week of each month. ${ }^{y}$ Chemical color determination calculated by dividing absorbance at $470 \mathrm{~nm}$ and at $455 \mathrm{~nm}$ of the acetone extracts.

Means within the same row with different superscript letter were significantly different at $p<0.05$ according to a Duncan (1955) multiple range test.

Table 2. Nutritional and chemical composition of paprika powder at different harvest times (mean \pm SD, $n=3)$ on a dry weight $(\mathrm{DW})$ basis.

\begin{tabular}{|c|c|c|c|c|}
\hline \multirow{2}{*}{ Parameters } & \multicolumn{4}{|c|}{ Sampling time $(\text { month })^{z}$} \\
\hline & September & October & November & December \\
\hline Carbohydrate (g/100 g DW) & $53.50 \pm 4.8$ & $55.96 \pm 3.3$ & $54.49 \pm 5.3$ & $55.33 \pm 4.8$ \\
\hline Protein (g/100 g DW) & $20.90 \pm 2.1$ & $20.19 \pm 2.6$ & $21.50 \pm 4.5$ & $20.28 \pm 2.6$ \\
\hline Lipid (g/100 g DW) & $8.28 \pm 0.6$ & $7.91 \pm 2.6$ & $7.55 \pm 3.9$ & $9.75 \pm 3.3$ \\
\hline Dietary fiber (g/100 g DW) & $35.05 \pm 1.4$ & $36.35 \pm 7.7$ & $37.07 \pm 3$ & $36.84 \pm 3.7$ \\
\hline Total sugar (g/100 g DW) & $6.88 \pm 0.47^{\mathrm{a}}$ & $9.47 \pm 0.21^{\mathrm{c}}$ & $11.19 \pm 0.11^{\mathrm{d}}$ & $7.73 \pm 0.41^{\mathrm{b}}$ \\
\hline Energy content $(\mathrm{kJ})$ & 1449.55 & 1512.32 & 1497.64 & 1573.17 \\
\hline Vitamin C (mg/100 g) & $1360.2 \pm 14.3^{\mathrm{a}}$ & $1830.2 \pm 39.4^{\mathrm{b}}$ & $1680.3 \pm 6.6^{\mathrm{b}}$ & $2020 \pm 32.3^{\mathrm{b}}$ \\
\hline Total capsaicinoids (mg/kg DW) & $48.4 \pm 5.7^{\mathrm{b}}$ & $33.1 \pm 3.8^{c}$ & $59.7 \pm 6.2^{\mathrm{a}}$ & $24.8 \pm 5.5^{\mathrm{d}}$ \\
\hline Scoville heat value & 73 & 535 & 938 & 398 \\
\hline Potassium (mg/100 g DW) & $2528 \pm 909$ & $2168 \pm 147$ & $2332 \pm 364$ & $2523 \pm 280$ \\
\hline Phosphorus (mg/100 g DW) & $393 \pm 30$ & $423 \pm 60$ & $363 \pm 43$ & $453 \pm 30$ \\
\hline Magnesium (mg/100 g DW) & $146 \pm 49$ & $136 \pm 24$ & $143 \pm 17$ & $130 \pm 15$ \\
\hline Calcium (mg/100 g DW) & $186 \pm 54^{\mathrm{a}}$ & $117 \pm 11^{\mathrm{b}}$ & $108 \pm 15^{\mathrm{b}}$ & $41.62 \pm 10^{c}$ \\
\hline Iron (mg/100 g DW) & $31 \pm 10$ & $53 \pm 15$ & $33 \pm 5$ & $42 \pm 6$ \\
\hline Sodium (mg/100 g DW) & $30 \pm 4^{\mathrm{b}}$ & $33 \pm 2^{b}$ & $34 \pm 6^{\mathrm{b}}$ & $71 \pm 9^{a}$ \\
\hline Copper (mg/100 g DW) & $1.06 \pm 0.5$ & $1.31 \pm 0.3$ & $1.18 \pm 0.3$ & $1.22 \pm 0.8$ \\
\hline Zinc (mg/100 g DW) & $1.67 \pm 0.2$ & $1.97 \pm 0.6$ & $2 \pm 0.2$ & $1.88 \pm 0.2$ \\
\hline Lead (mg/100 g DW) & nd & nd & nd & nd \\
\hline Cadmium (mg/100 g DW) & nd & nd & nd & nd \\
\hline
\end{tabular}

${ }^{2}$ Samples were obtained in triplicate in the first week of each month. Means within the same row with different superscript letter were significantly different at $p<0.05$ according to a Duncan (1955) multiple range test. nd: non detectable. 


\subsection{Chemical and nutritional qualities of paprika}

There was no significant effect of sampling time on the carbohydrate, protein, lipid and dietary fiber contents (Table 2). As reported by FAO (FOOD..., 2009), dried peppers (Capsicum annuum) contain $12.8 \%$ protein, $11.9 \%$ fat, $56.2 \%$ carbohydrate and $22.5 \%$ fiber. In this study (Table 2), the paprika powder exhibited a similar carbohydrate content (around 55\%) and lower lipid content (around 8\%), but higher fiber (around 36\%) and protein (around 21\%) values.

In the case of total sugar, a significant difference between sampling times was observed, with a maximum obtained in November $(11.19 \%)$, which is close to the $10.4 \%$ reported by the National Nutrient Database for Standard Reference (U.S. DEPARTMENT..., 2009). The energy value ranged from 1498 to $1573 \mathrm{~kJ} 100 \mathrm{~g}^{-1}$ DW, while FAO (FOOD..., 2009) mentioned a value of about $1384 \mathrm{~kJ} 100 \mathrm{~g}^{-1} \mathrm{DW}$.

The vitamin C concentrations in paprika ranged from 1360 to $2020 \mathrm{mg} 100 \mathrm{~g} \mathrm{~g}^{-1} \mathrm{DW}$, which agrees with the values obtained by Kim et al. (2011) (1987 mg $100 \mathrm{~g}^{-1}$ DW). However, vitamin $\mathrm{C}$ levels vary greatly among cultivars. For example, Deepa et al. (2007) reported that sweet pepper genotypes harvested at the red stage used for paprika processing may show values ranging from 647 to $2135 \mathrm{mg} 100 \mathrm{~g}^{-1} \mathrm{DW}$.

The total capsaicinoid content varied significantly between harvest dates between 25 and $60 \mu \mathrm{g} \mathrm{g}^{-1}$. Govindarajan, Narasimhan and Dhanaraj (1977) indicated that sweet paprika

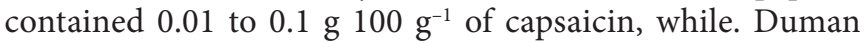
(2010) obtained $89.8 \mathrm{mg} \mathrm{kg}^{-1}$ of total capsicinoid in dried red chili pepper in Turkey. The Scoville index calculated ranged between 398 and 938 heat units, classifying our samples as sweet paprika. Typical pungency ranges of sweet paprika are 0 to 700 Scoville heat units (BOSLAND; VOTAVA, 2000). The capsaicin content of pepper fruits varies according to the ontogenetic variety, ecological conditions of the habitat, cultivar adaptation to climate, crop management, the age of the fruit and harvest time, and the position of the fruit on the plant (BHARATHI et al.; 2011; GOVINDARAJAN, 1985; HUNDAL; KHANNA, 2002; PERUCKA; OLESZEK, 2000).
Particularly rainfall above a certain level during fruit growth and ripening and, in this case, irrespective of maximum average temperatures, had an impact reducing capsaicinoid levels (Table 2), as does the age of the fruit (ESTRADA et al., 2002; TITZE; MUELLER-SEITZ; PETZ, 2002). Perhaps rainfall enhanced peroxidase activities, which are frequently associated with stress and inversely correlated with capsaicinoid levels in pepper (CONTRERAS-PADILLA; YAHIA, 1998). Processing (particularly the drying conditions and the number of seeds included) also could have some influence on pungency (TITZE; MUELLER-SEITZ; PETZ, 2002).

Paprika samples were rich in potassium, phosphorus, calcium and magnesium, and relatively poor in sodium, while heavy metals $(\mathrm{Pb}, \mathrm{Cd})$ were not detected. Tepić et al. (2008) obtained similar results in Serbian paprika. The concentrations of $\mathrm{Cu}$ and $\mathrm{Zn}$ were within EU limits (EUROPEAN..., 2006). The only minerals affected by sampling time were calcium and sodium (Table 2). The level of Na was significantly higher in December samples, while the calcium content decreased gradually from September to December.

Linoleic (18:2), oleic (18:1) and palmitic (16:0) acids were the predominant fatty acids in paprika powders (Table 3), as also reported by Asilbekova (2003). The other fatty acids were detected in lower percentages. Unsaturated fatty acids represented $84.7-88.6 \%$ of the total fatty acids present, with predominance of unsaturated linoleic acid (70.3-71.7\%). Similar results were obtained by Govindarajan (1985). The fatty acid composition of paprika powder was related to the mixing ratio between the pericarp and the seeds. The origin of linoleic acid is mainly related with the seeds (PÉREZ-GÁLVEZ; GARRIDOFERNÁNDEZ; MÍNGUEZ-MOSQUERA, 1999). The high amount of linoleic acid in paprika, an omega- 6 and well-known essential fatty acid for humans, contributes to its nutritive value. The ratio between saturated and unsaturated fatty acids in the paprika powders ranged from 0.13 to 0.17 , in agreement with other paprika powders obtained in Spain (PÉREZ-GÁLVEZ; GARRIDO-FERNÁNDEZ; MÍNGUEZ-MOSQUERA, 1999). A predominance of unsaturated fatty acids is believed to be related

Table 3. Fatty acid composition of paprika powder in a unique analysis obtained by mixing sub-samples of each replicate.

\begin{tabular}{|c|c|c|c|c|}
\hline \multirow{2}{*}{$\begin{array}{c}\text { Fatty acid } \\
(\% \mathrm{w} / \mathrm{w})\end{array}$} & \multicolumn{4}{|c|}{ Sampling time (month) ${ }^{\mathrm{z}}$} \\
\hline & September & October & November & December \\
\hline $\mathrm{C}_{18}^{2}:$ Linoleic & 71.7 & 0.3 & 70.9 & 71.3 \\
\hline $\mathrm{C}_{18}^{1}$ : Oleic & 9.5 & 10.3 & 12.8 & 9.5 \\
\hline $\mathrm{C}_{16}^{0}$ : Palmitic & 10.7 & 10.9 & 7.7 & 10.7 \\
\hline $\mathrm{C}_{18}{ }^{3}$ : Linolenic & 3.1 & 3.5 & 3.6 & 3.1 \\
\hline $\mathrm{C}_{18}^{0}:$ Stearic & 2.7 & 2.7 & 2.2 & 2.7 \\
\hline $\mathrm{C}_{14}{ }^{0}$ : Myristic & 0.1 & 0.5 & 1 & 0.1 \\
\hline $\mathrm{C}_{16}{ }^{1}:$ Palmitoleic & 0.4 & 0.5 & 0.4 & 0.9 \\
\hline $\mathrm{C}_{20}^{0}$ : Arachidic & 0.4 & 0.3 & 0.4 & 0.4 \\
\hline $\mathrm{C}_{20}{ }^{1}$ : Gadoleic & 0.2 & 0.1 & 0.3 & 0.2 \\
\hline Other fatty acids & 1.2 & 0.9 & 0.7 & 1.1 \\
\hline$\%$ Saturated fatty acid & 13.9 & 14.4 & 11.4 & 13.9 \\
\hline$\%$ Unsaturated fatty acid & 84.9 & 84.7 & 88.6 & 85 \\
\hline S/U Ratio & 0.16 & 0.17 & 0.13 & 0.16 \\
\hline
\end{tabular}


Table 4. Evolution of microbiological parameters in paprika powders during the sampling time (mean, $\mathrm{n}=3)$. Clostridium, Salmonella and total aflatoxins were not detected (n.d.).

\begin{tabular}{lcccc}
\hline \multicolumn{1}{c}{$\begin{array}{c}\text { Parameters } \\
\text { (CFU/g) }\end{array}$} & September & October & November & December \\
\cline { 2 - 5 } & $7.4 \times 10^{6}$ & $2.1 \times 10^{7}$ & $2.3 \times 10^{7}$ & $3.6 \times 10^{7}$ \\
\hline TAMB $^{\text {y }}$ & $1.5 \times 10^{5}$ & $8.7 \times 10^{5}$ & $1.5 \times 10^{6}$ & $2.7 \times 10^{6}$ \\
Total enterobacteria & $4 \times 10^{5}$ & $1.1 \times 10^{6}$ & $1.7 \times 10^{6}$ & $5.5 \times 10^{6}$ \\
Total coliform & $6.9 \times 10^{4}$ & $1.7 \times 10^{3}$ & $1.3 \times 10^{5}$ & $4.7 \times 10^{5}$ \\
Fecal coliform & $6.2 \times 10^{4}$ & $2.5 \times 10^{6}$ & $1.8 \times 10^{6}$ & $3.8 \times 10^{6}$ \\
Staphylococcus & nd & nd & $5.7 \times 10^{4}$ & $3 \times 10^{5}$ \\
Streptococcus & & & & \\
\hline
\end{tabular}

${ }^{2}$ Samples were obtained in triplicate in the first week of each month. ${ }^{y}$ Total aerobic mesophilic bacteria.

with the stability of the powdered product (PÉREZ-GÁLVEZ; GARRIDO-FERNÁNDEZ; MÍNGUEZ-MOSQUERA, 1999).

\subsection{Microbiological quality of paprika powders}

The microbial load generally increased over time (Table 4). The mesophilic aerobic bacteria counts obtained (Table 4) were above the maximum permitted levels (INTERNATIONAL..., 1986). Banerjee and Sarkar (2003) and Gallardo-Guerrero et al. (2010) also obtained values above $10^{6} \mathrm{CFU} \mathrm{g}^{-1}$ limits.

The levels of total enterobacteria and coliforms in paprika powder are indicative of the hygiene status of both the raw material and the paprika manufacturing process, the bacteria reached values of $2.7 \times 10^{6}$ and $5.5 \times 10^{6} \mathrm{CFU}$, respectively, in the December samples. These values were higher than those obtained by Gallardo-Guerrero et al. (2010), Rico et al. (2010) and Calvo and Torres (2010). However, the high levels of fecal coliform found indicated that better processing practices should be implemented in order to avoid exceeding the recommended safe level (<100 coliform/g) (PELCZAR; CHAN; NOEL, 2005).

The most serious problems in paprika particularly evolve from Salmonella species and Clostridium perfringens (CANDLISH et al., 2001). Salmonella and Clostridium were not detected in all samples investigated. Aflatoxins, considered a major problem in paprika and chili (FLANNIGAN; HUI, 1976) were not detected in the samples investigated. Yeasts and moulds were present in lower counts (not quantified) and Penicillium sp. and Aspergillus sp. were detected. However, Streptococcus, an indicator of fecal contamination, was detected only in the samples of November and December at levels also above the results reported by Gallardo-Guerrero et al. (2010).

The increase in microbial load can be explained by the decrease in the temperature at which the paprika is dried (in the sun) from September to December. Low temperatures favor the growth of microorganisms and increase the drying time, thereby exposing the fruit to various types of contamination and unfavorable meteorological conditions (dew, rain, etc.). Therefore, the high microbial loads measured can be attributed to various sources, including crop management, the environment, and the faeces of birds and other animals, the red pepper fruits being contaminated during cultivation or during the processing time (drying in contact with a compact soil), assuming that the grinding, milling, packaging and other postharvest processing operations were the same (HAKMAOUI; OUATMANE; FERNÁNDEZ-TRUJILLO, 2011).

\section{Conclusions}

This is the first report on the composition of paprika from the main production area in Morocco (Tadla Region). This paprika showed the nutritional and physical-chemical quality attributes required by international standards, although the microbial load for some of the microorganisms studied was exceeded. Maximum paprika ASTA color values were obtained in November samples while the levels of vitamin C were higher from October to December. Sampling time mainly affected color, and the total capsaicinoid and vitamin $\mathrm{C}$ contents. A change in the drying protocols, accompanied by improved hygiene in the paprika plants, is necessary to reduce the microbial load. If this is not carried out, the paprika of this region should be subjected to treatments to reduce microbial load without compromising its color and vitamin $\mathrm{C}$ content.

\section{Acknowledgements}

The authors are very grateful to Prof. Hassan Latrache (Faculté des Sciences et Techniques, Beni Mellal, Maroc) for helping in the microbiological analysis. Abdelmalek Hakmaoui is indebted to the Ministry of Foreign Affairs of Spain for a MAE-AECI postdoctoral fellowship at UPCT.

\section{References}

AIZAWA, K.; INAKUMA, T. Dietary capsanthin, the main carotenoid in paprika (Capsicum annuum), alters plasma high-density lipoprotein-cholesterol levels and hepatic gene expression in rats. British Journal of Nutrition, v. 102, p. 1760-1766, 2009. http:// dx.doi.org/10.1017/S0007114509991309

ASILBEKOVA, D. T. Lipids of Capsicum annuum fruit pulp. Chemistry of Natural Compounds, v. 39, p. 442-445, 2003. http://dx.doi. org/10.1023/B:CONC.0000011116.56095.ae

AMERICAN SPICE TRADE ASSOCIATION - ASTA. ASTA Cleanliness specifications for spices, seeds, and herbs. Engelwoods Cliff: ASTA, 1999.

ASSOCIATION OF OFFICIAL ANALYTICAL CHEMISTS INTERNATIONAL - AOAC. 43.1.02 Color Extractable in Spices. AOAC methods 971.26. In: HORWITZ, W. (Ed.). Official Methods of Analysis of the Association of Official Analytical Chemists International. 17th ed. Gaithrsburg: AOAC, 2002. v. 2. 
BANERJEE, M.; SARKAR, P. Microbiological quality of some retail spices in India. Food Research International, v. 36, p. 469-474, 2003. http://dx.doi.org/10.1016/S0963-9969(02)00194-1

BENDERITTER, M. et al. Studies by electron paramagnetic resonance of the importance of iron in the hydroxyl scavenging properties of ascorbic acid in plasma: Effects of iron chelators. Fundamental and Clinical Pharmacology, v. 12, p. 510-516, 1998. http://dx.doi. org/10.1111/j.1472-8206.1998.tb00979.x

BHARATHI, L. K. et al. Estimation of capsaicin and capsaicinoid contents of high pungent chilli accessions of Andaman \& Nicobar Islands and North-East India. Indian Journal of Horticulture, v. 68, p. 551-555, 2011. Disponível em: <www.indianjournals.com/ijor. aspx ?target $=$ ijor $: i j h \&$ volume $=68 \&$ issue $=4 \&$ article $=019>$. Acesso em: 16 ago. 2013.

BOSLAND, P. W.; VOTAVA, E. J. Peppers: Vegetable and spice Capsicums. CAB Intl Pub, 2000.

BROWNE, C. A.; ZERBAN, F. W. Physical and chemical methods of sugar analysis. New York: John Wiley and Sons, 1955.

BUCKENHÜSKES, H. J. Current requirements on paprika powder for food industry. In: KRISHNA, A. (Ed.). Capsicum: The genus Capsicum. London: Taylor and Francis Ltd., 2003. p. 223-230.

CALVO, L.; TORRES, E. Microbial inactivation of paprika using highpressure $\mathrm{CO}_{2}$. Journal of Supercritcal Fluids, v. 52, p. 134-141, 2010. http://dx.doi.org/10.1016/j.supflu.2009.11.002

CANDLISH, A. A. G. et al. A survey of ethnic foods for microbial quality and aflatoxin content. Food Additives and Contaminants, v. 18, p. 129-136, 2001.

CARVAJAL, M. et al. Effect of ascorbic acid addition peppers on paprika quality. Journal of the Science of Food and Agriculture, v. 75, p. 442-446, 1997. http://dx.doi.org/10.1002(SI CI)1097-0010(199712)

COLLINS, M.; WASMUND, L. M.; BOSLAND, P. W. Improved method for quantifying capsaicinoids in Capsicum using highperformance liquid chromatography. HortScience, v. 30, p. 137139, 1995. Disponível em: <http://hortsci.ashspublications.org/ content/30/1/137.full.pdf>. Acesso em: 16 ago. 2013.

CONDORI, M.; SARAVIA, L. Solar drying of sweet pepper and garlic using the tunnel greenhouse drier. Renewable Energy, v. 22, p. 447460, 2001. http://dx.doi.org/10.1016/S0960-1481(00)00098-7

CONTRERAS-PADILLA, M.; YAHIA, E. M. Changes in capsaicinoids during development, maturation, and senescence of Chile peppers and relation with peroxidase activity. Journal of Agricultural and Food Chemistry, v. 46, p. 2075-2079, 1998. http://dx.doi. org/10.1021/jf970972z

DEEPA, N. et al. Antioxidant constituents in some sweet pepper (Capsicum annuum L.) genotypes during maturity. Food Science and Technology, v. 40, p. 121-129, 2007. http://dx.doi.org/10.1016/j. lwt.2005.09.016

DE GUEVARA, R. G.-L. et al. Evolution of color during the ripening of selected varieties of paprika pepper (Capsicum annuum L.). Journal of Agricultural and Food Chemistry, v. 44, p. 2049-2052, 1996. http://dx.doi.org/10.1021/jf950465m

DELI, J.; PFANDER, H.; TÓTH, G. Investigation of carotenoid composition of paprika paste. Chromatographia, v. 56, p. S-177179, 2002. http://dx.doi.org/10.1007/BF02494134
DOUGLAS, M.; HEYES, J.; SMALLFIELD, B. Herbs, Spices and Essential oils: Postharvest Operations in Developing Countries, 2005. Disponível em: <www.fao.org >. Acesso em: 10 fev. 2013.

DOYMAZ, I.; PALA, M. Hot-air drying characteristics of red pepper. Journal of Food Engineering, v. 55, p. 331-335, 2002. http://dx.doi. org/10.1016/S0260-8774(02)00110-3

DUNCAN, D. B. Multiple range and multiple F tests. Biometrics, v. 11, p. 1-42, 1955.

DUMAN, A. D. Storage of red chili pepper under hermetically sealed or vacuum conditions for preservation of its quality and prevention of mycotoxin occurrence. The Journal of Stored Products Research, v. 46, p. 155-160, 2010. http://dx.doi.org/10.1016/j.jspr.2010.02.002

DURUCASU, I.; TOKUSOGLU, O. Effects of grilling on luteolin (3',4'5,7-tetrahydroxyflavone) content in sweet green bell pepper (Capsicum annuum). Pakistan Journal of Biological Sciences, v. 10, p. 3410-3414, 2007. http://dx.doi.org/10.3923/pjbs.2007.3410.3414

ESCARABAJAL, D.; FERNÁNDEZ-TRUJILLO, J. P. La tecnología de la fabricación del pimentón en Murcia. Alimentaria, v. 400, p. 116-120, 2009.

ESTRADA, B. et al. Capsaicinoids in vegetative organs of Capsicum annuum L. In relation to fruiting. Journal of Agricultural and Food Chemistry, v. 50, p. 1188-1191, 2002. http://dx.doi.org/10.1021/ jf011270j

EUROPEAN COMMISSION. Regulation no EC/1881/2006, of 19 december 2006. Setting maximum levels for certain contaminants in foodstuffs. Official Journal of the European Union, $20 \mathrm{dez}$. 2006. L 364/5-L 364/24.

EUROPEAN STANDARD. ISO 12966-2 Animal and vegetable fats and oils, Gas chromatography of fatty acid methyl esters - Part 2: Preparation of methyl esters of fatty acids. Wien: Austrian Standards Institute, 2011.

FOOD AND AGRICULTURE ORGANIZATION OF THE UNITED NATIONS - FAO. Food Composition Table for Vegetables and Fruits. FAO, 2009. Disponível em: <www.fao.org/infoods/index_ en.htm>. Acesso em: 10 fev. 2013.

FERNÁNDEZ-TRUJILLO, J. P. Extracción convencional de oleorresina de pimentón dulce y picante I. Generalidades, composición, proceso e innovaciones y aplicaciones. Grasas y Aceites, v. 58, p. 152-163, 2007. Disponível em: <http://grasasyaceites.revistas.csic.es/index. php/grasasyaceites/article/viewFile/180/180>. Acesso em: 16 ago. 2013.

FERNÁNDEZ-TRUJILLO, J. P.; ESCARABAJAL, D. El proceso tradicional de elaboración del pimentón de Murcia y sus posibles innovaciones. Grasas y Aceites, v. 57, p. 433-442, 2006. Disponível em: <http:/grasasyaceites.revistas.csic.es/index.php/grasasyaceites/ article/view/71/68>. Acesso em: 16 ago. 2013.

FLANNIGAN, B.; HUI, S. C. The occurrence of aflatoxin-producing strains of Aspergillus flavus in the mould floras of ground spices. Journal of Applied Bacteriology, v. 41, p. 411-418, 1976. http:// dx.doi.org/10.1111/j.1365-2672.1976.tb00653.x

GALLARDO-GUERRERO, L. et al. Physicochemical and microbiological characterization of the dehydration processing of red pepper fruits for paprika production. LWT-Food Science and Technology, v. 43, p. 1359-1367, 2010. http://dx.doi.org/10.1016/j. lwt.2010.04.015

GILBERT, J.; ANKLAM, E. Validation of analytical methods for determining mycotoxins in foodstuffs. Trends in Analytical 
Chemistry, v. 21, p. 468-486, 2002. http://dx.doi.org/10.1016/ S0165-9936(02)00604-0

GOVINDARAJAN, V. S. Capsicum production. Technology, chemistry and quality, part I: History, botany, cultivation and primary processing. Critical Reviews in Food Science and Nutrition, v. 22, p. 109-176, 1985. http://dx.doi.org/10.1080/10408398509527412

GOVINDARAJAN, V. S.; NARASIMHAN, S.; DHANARAJ, S. Evaluation of spices and oleoresins, 2. pungency of capsicum by scotville heat units - standardized procedure. Journal of Food Science and Technology - Mysore, v. 14, p. 28-34, 1977.

HAKMAOUI, A.; OUATMANE, A.; FERNÁNDEZ-TRUJILLO, J. P. El cultivo de la ñora y la industria del pimentón en la región de TadlaAzilal (Marruecos). Horticultura, v. 295, p. 31-35, 2011. Disponível em: <http://www.interempresas.net/Horticola/Articulos/49594-Elcultivo-de-la-nora-y-la-industria-del-pimenton-en-la-region-deTadla-Azilal-(Marruecos).html>. Acesso em: 16 ago. 2013.

HORNERO-MÉNDEZ, D.; MÍNGUEZ-MOSQUERA, M. I. Rapid spectrophotometric determination of red and yellow isochromic carotenoid fractions in paprika and red pepper oleoresins. Journal of Agricultural and Food Chemistry, v. 49, p. 3584-3588, 2001. http://dx.doi.org/10.1021/jf0104001

HORWITZ, W. Spices and Other Condiments, Color Extractable in Spices. In: HORWITZ, W. (Ed.). Official Methods of Analysis of the Association of Official Analytical Chemists International. 17th ed. Gaithrsburg: AOAC, 2002. v. II.

HUNDAL, J. S.; KHANNA, D. S. A new hybrid off Chili "Ch-3" suitable for processing. Journal of Research of the Punjab Agricultural University, v. 39, p. 326, 2002. Disponível em: <http:// www.indianjournals.com/ijor.aspx?target=ijor:jre\&volume $=39$ \&is sue $=2 \&$ article $=025>$. Acesso em: 16 ago. 2013.

INTERNATIONAL COMMISSION ON MICROBIOLOGICAL SPECIFICATIONS FOR FOODS - ICMSF. Microorganisms in foods 2. Sampling for microbiological analysis: Principles and specific applications.Oxford: Blackwell Scientific Pub., 1986.

JACKSON, M. L. Nanadomolybdophosphoric yellow color method in nitric acid system. In: SOIL Chemical Analysis. Madison: University of Wisconsin, 1985.

KIM, D. Y.; RHEE, C. O.; SHIN, S. C. Changes in colour of red pepper during drying and milling. Journal of Korean Agricultural and Chemical Society, v. 25, p. 1-7, 1982.

KIM, S.; PARK, J. B.; HWANG, I. K. Quality attributes of various varieties of Korean red pepper powders (Capsicum annuum L.) and color stability during sunlight exposure. Journal of Food Science, v. 67, p. 2957-2961, 2002. http://dx.doi.org/10.1111/j.1365-2621.2002. tb08845.x

KIM, J. S. et al. Phytochemicals and antioxidant activity of fruits and leaves of paprika (Capsicum annuum L.; var. special) cultivated in Korea. Journal of Food Science, v. 76, p. 193-198, 2011. http:// dx.doi.org/10.1111/j.1750-3841.2010.01891.x

LEE, D. S.; CHUNG, S. K.; YAM, K. L. Carotenoid loss in dried red pepper products. International Journal of Food Science and Technology, v. 27, p. 179-185, 1992. http://dx.doi.org/10.1111/j.1365-2621.1992. tb01194.x

MÁRKUS, F. et al. Change in the carotenoid and antioxidant content of spice red pepper (paprika as a function of ripening and some technological factors. Journal of Agricultural Food Chemistry, v. 47, p. 100-107, 1999. http://dx.doi.org/10.1021/jf980485z
McGUIRE, R. G. Reporting of objective color measurements. HortScience, v. 27, p. 1254-1255, 1992. Disponível em: $<$ http://hortsci.ashspublications.org/content/27/12/1254.full. pdf\%2Bhtml>. Acesso em: 16 ago. 2013.

MÍNGUEZ-MOSQUERA, M. I.; HORNERO-MÉNDEZ, D. Comparative study of the effect of paprika processing on the carotenoids in peppers (Capsicum annuum) of the Bola and Agridulce varieties. Journal of Agricultural and Food Chemistry, v. 42, p. 1555-1560, 1994. http://dx.doi.org/10.1021/jf00043a031

MÍNGUEZ-MOSQUERA, M. I.; JARÉN-GALÁN, M.; GARRIDOFERNÁNDEZ, J. Competition between the processes of biosynthesis and degradation of carotenoids during the drying of peppers. Journal of Agricultural and Food Chemistry, v. 42, p. 645-648, 1994. http://dx.doi.org/10.1021/jf00039a008

OBEROI, H. S. et al. Quality of red chilli variety as affected by different drying methods. Journal of Food Science and Technology - Mysore, v. 42, p. 384-387, 2005.

OSBORNE, D.; VOOGT, P. Official Methods 6.2, 6.3. In: OSBORNE, D.; VOOGT, P. The analysis of nutrients in foods. London: Academic Press Inc., 1978.

PELCZAR, M. J.; CHAN, E. C. S.; NOEL, R. K. C. Microbiology. 5th ed. New Delhi: Tata McGraw Hill, 2005.

PÉREZ-GÁLVEZ, A.; GARRIDO-FERNÁNDEZ, J.; MÍNGUEZMOSQUERA, M. I. Fatty acid composition of two new pepper varieties (Capsicum annuum L. cv Jaranda and Jariza. Effect of drying process and nutritional aspects. Journal of the American Oil Chemists' Society, v. 76, p. 205-208, 1999. http://dx.doi. org/10.1007/s11746-999-0219-8

PÉREZ-GÁLVEZ, A. et al. Correlación entre unidades astaconcentracion carotenoide en pimentones predicción de la estabilidad del color durante el almacenamiento. Grasas y Aceites, v. 55, p. 213-218, 2004. http://dx.doi.org/10.3989/gya.2004.v55. i3.168

PÉREZ-GÁlVEZ, A.; HORNERO-MÉNDEZ, D.; MÍNGUEZMOSQUERA, M. I. Stability of paprika without supplementary antioxidants during storage under industrial controlled conditions. Journal of Agricultural and Food Chemistry, v. 57, p. 4718-4723, 2009. http://dx.doi.org/10.1021/jf804058m

PÉREZ-GÁlVEZ, A.; HORNERO-MÉNDEZ, D.; MÍNGUEZMOSQUERA, M. I. Changes in the carotenoid metabolism of capsicum fruits during application of modelized slow drying process for paprika production. Journal of Agricultural and Food Chemistry, v. 52, p. 518-522, 2004. http://dx.doi.org/10.1021/ jf0350616

PERUCKA, I.; MATERSKA, M. Phenylalanine ammonia-lyase and antioxidant activities of lipophilic fraction of fresh pepper fruits Capsicum annuum L. Innovative Food Science and Emerging Technologies, v. 2, p. 189-192, 2001. http://dx.doi.org/10.1016/ S1466-8564(01)00022-4

PERUCKA, I.; OLESZEK W. Extraction and determination of capsaicinoids in fruit of hot pepper Capsicum annuum L. By spectrophotometry and high-performance liquid chromatography. Food Chemistry, v. 71, p. 287-91, 2000. doi.org/10.1016/S0308$8146(00) 00153-9$

POMERANZ, Y.; CLIFTON, M. E. Food Analysis: Theory and Practice. New-York: Van Nostrand Reinold, 1987. 
PROSKY, L. et al. Determination of insoluble and soluble dietary fiber in foods and food products. Journal of the Association of Official Analytical Chemists, v. 75, p. 360-367, 1992.

RICO, C. W. et al. The comparative effect of steaming and irradiation on the physicochemical and microbiological properties of dried red pepper (Capsicum annuum L.). Food Chemistry, v. 119, p. 10121016, 2010. http://dx.doi.org/10.1016/j.foodchem.2009.08.005

SCHWEIGGERT, U.; CARLE, R.; SCHIEBER, A. Characterization of major and minor capsaicinoids and related compounds in chili pods (Capsicum frutescens L.) by high performance liquid chromatography/atmospheric pressure chemical ionization mass spectrometry. Analytica Chimica Acta, v. 557, p. 236-244, 2006. http://dx.doi.org/10.1007/s00217-006-0413-y

TEPIĆ, A. N. et al. Quality of commercial ground paprika and its oleoresins. Acta Periodica Technologica, v. 39, p. 77-83, 2008. http://dx.doi.org/10.2298/APT0839077T

TITZE, K. P.; MUELLER-SEITZ, E.; PETZ, M. Pungency in paprika (capsicum annuum). 2. Heterogeneity of capsaicinoid content in individual fruits from one plant. Journal of Agricultural and Food Chemistry, v. 50, p. 1264-1266, 2002. http://dx.doi.org/10.1021/ jf0105283

TODD JUNIOR, P. H.; BENSINGER, M. G.; BIFTU, T. Determination of pungency due to Capsicum by gas-liquid chromatography. Journal of Chromatography, v. 367, p. 438-442, 1977. http://dx.doi. org/10.1111/j.1365-2621.1977.tb12573.x

TOPUZ, A. A novel approach for color degradation kinetics of paprika as a function of water activity. LWT-Food Science and
Technology, v. 41, p. 1672-1677, 2008. http://dx.doi.org/10.1016/j. lwt.2007.10.004

TOPUZ, A.; FENG, H.; KUSHAD, M. The effect of drying method and storage on colour characteristics of paprika. Journal of Food Science and Technology - Mysore, v. 42, p. 1667-1673, 2009. http:// dx.doi.org/10.1016/j.lwt.2009.05.014

U.S. DEPARTMENT OF AGRICULTURE - USDA. Agricultural Research Service. USDA Nutrient Database for Standard Reference. Nutrient Data Laboratory 2009. Disponível em: <http:// www.nal.usda.gov/fnic/foodcomp/search>.

VALLE-ALGARRA, F. M. et al. Determination of type A and type $B$ trichothecenes in paprika and chili pepper using LC-triple quadrupole-MS and GC-ECD. Talanta, v. 84, p. 1112-1117, 2011. http://dx.doi.org/10.1016/j.talanta.2011.03.017

VEGA-GÁLVEZ, A. et al. Effect of air drying temperature on the quality of rehydrated dried red bell pepper (var. Lamuyo). Journal of Food Engineering, v. 85, p. 42-50, 2008. http://dx.doi.org/10.1016/j. jfoodeng.2007.06.032

YALDIZ, G.; OZGUVEN, M.; SEKEROGLU, N. Variation in capsaicin contents of different Capsicum species and lines by varying drying parameters. Industrial Crops and Products, v. 32, p. 434-438, 2010. http://dx.doi.org/10.1016/j.indcrop.2010.06.013 